\title{
A Study of Documentary Sources \\ Relating to Women's Right to \\ Divorce in Ancient Judea \\ Brittany Crockett
}

\begin{abstract}
This paper examines the concept and treatment of divorce in ancient Judea as a historical reality rather than a theological issue, focusing particularly on the idea of the wife as the active party in the divorce. Did women in Judea have the right to initiate divorce? It seems the answer might have been yes. The implications of several key documentary sources, including various marriage and legal contracts relating to divorce are discussed. The paper concludes with a brief look at several scriptural precedents for divorce. Both the historical merit and historiographical problems with these ancient sources are addressed.
\end{abstract}

Very few extant extra-biblical sources document divorce practices in the ancient Judaic community during what might be considered biblical times, but the sparse evidence seems to indicate that divorces did occur and might even have been common. There are two principal schools of thought on the issue of which party could initiate the divorce. The first position, based on scriptural depictions of women and Talmudic law, holds that "divorce was legally admitted in all ancient Near Eastern societies, but as an almost exclusive male prerogative." The idea is that women could obtain divorce on their own behalf only by appealing to a rabbinic court and obtaining an order forcing the husband to divorce her. However, certain primary sources - such as those examined here - have given rise to a counterargument 
supported by scholars like Tal Ilan, which posits that some women could initiate divorce on their own prerogative, without the explicit consent or command of the husband. ${ }^{2}$ Documents found in Elephantine, Egypt include marriage contracts from a relatively early Judaic community which appear to include divorce or "repudiation" clauses. These marriage documents are comparable to a few much later Romano-Judaic documents found at Se'elim, in Judea. Among these documents from Judea are two bills of divorce dating from the Roman period - the Masada get, a bill of divorce from the husband to the wife, and the controversial Papyrus Se'elim 13, which can be interpreted as a divorce bill initiated by the wife and given to her husband. ${ }^{3}$ This paper is primarily concerned with the rights and roles of women in the context of these marriage and divorce contracts, paying particular attention to the question of whether or not the woman could initiate divorce proceedings against her husband. The discussion of documentary evidence will focus specifically on the Elephantine marriage documents and Papyrus Se'elim 13. These contracts, which appear to indicate that women in the Judaic community at least occasionally had the power to divorce their husbands, are widely separated in time, with nearly six centuries between the Elephantine documents and Papyrus Se'elim 13. The linking factor is that both represent interpretations of divorce law belonging to the same theological tradition. 
Considering this theological aspect, the scriptural basis for the views on divorce presented in the Elephantine contracts and in Papyrus Se'elim 13 must be considered. These primary sources will be contrasted against several Old Testament sources relating to the subject of divorce, particularly the example in the book of Hosea and the codes of marital law presented in Exodus and Deuteronomy. ${ }^{4}$ The goal is to gain a perspective on women's roles in divorce proceedings and contracts in the ancient Judaic community through a comparison of these primary documentary and scriptural sources spanning a wide period of time. ${ }^{5}$

The earlier of the two sets of documentary sources to be examined are the marriage contracts found at the Egyptian island community of Elephantine, which date to 449-420 BCE. ${ }^{6}$ Elephantine was a garrison community from mixed cultural backgrounds, but these Aramaic contracts clearly belong to the Judaic tradition. Although the documents from Elephantine include three separate marriage contracts, all three have similar forms and address the issue of potential divorce in a similar manner; all three documents are discussed as a set. These contracts are specifically documents of wifehood outlining the terms of marriage, including an affirmation of married status, the dowry, clauses in case of the death of either the husband or wife and, most importantly for this discussion, repudiation clauses whereby either the husband or wife may end the marriage. ${ }^{7}$ In each case, the contract specifies that 
"tomorrow or the next day, should [the wife] stand up in an assembly and say: 'I hated [the husband,]' silver of hatred is on her head," and the husband may also invoke this clause. ${ }^{8}$ This price being paid, the marriage is ended. It should be noted that despite the presence of these reciprocal repudiation clauses, the word 'divorce' does not appear anywhere in the Elephantine contracts. ${ }^{9}$ They do not explicitly state the right to divorce, either on the husband's or wife's behalf. Rather, the repudiation clauses deal with the financial concerns surrounding the act of divorce, just as the contracts as a whole deal with the financial concerns of marriage, the dowry and mohar. ${ }^{10}$ Each document specifies the exact price of the repudiation, the "silver of hatred;" always the same seven and a half sheckels, whether the initiator is the husband or the wife. ${ }^{11} \mathrm{H}$. Nutkowicz's "Concerning the Verb śn' in Judaeo-Aramaic Contracts from Elephantine" claims that this payment of silver "entitles one to buy the right to separation." ${ }^{12}$ The documents of wifehood from Elephantine are in essence financial contracts and not bills of rights, and the right to divorce (or merely the fact of divorce) is implicit by its matter-of-fact inclusion in those contracts. Since this right is clearly already present in society at Elephantine, the right to divorce does not need to be purchased; the inclusion of the repudiation clauses indicates a financial obligation to be carried out upon the invoking of that right. It is interesting to note that this implied divorce right extends equally not just to wives but to slave wives, as in the Elephantine contract detailing the marriage of Tamet, a 
handmaiden. Although in other respects Tamet's document of wifehood differs financially from the other Elephantine contracts because of her slave status - for example, the lack of mohar - the silver of hatred remains the same amount. ${ }^{13}$ The Elephantine contracts present divorce as a contractual contingency, a legal recourse to which both men and women had equal rights and which, when used, exacted equal financial penalties regardless of sex or class.

Papyrus Se'elim 13, a papyrus belonging to a cache of Roman-era Jewish documents known as the Se'elim archive, offers a much later (second century CE) documentary source on the existence and financial repercussions of divorce. ${ }^{14}$ This papyrus is not a marriage contract, as is the Elephantine document, but a contract of a different kind: either a divorce bill or perhaps a receipt of divorce payment. In part because it is more fragmentary than the well-preserved Elephantine contracts and much more recently published, Papyrus Se'elim 13 is also the subject of controversy where the Elephantine documents are not. Differences in translation and interpretation have led to considering Papyrus Se'elim 13 variously as a receipt of divorce payment given by the wife to her divorcing husband, a divorce bill given by a divorcing woman to her husband, a receipt of bill of divorce given by the wife to her divorcing husband, and a divorce certificate written on behalf of the divorcing wife to her husband. ${ }^{15}$ So, unlike the Elephantine contracts, Papyrus Se'elim 13 offers very 
little insight as to how common or accepted the practice of divorce was in the general community. Scholars cannot even agree upon the type of document that the papyrus represents.

It is clear, however, that divorce did occur within the Jewish community during this time period. It should be noted that, after the second century BCE, Greco-Roman influence becomes a complicating factor in the discussion of any aspect of Israelite culture, including family law and divorce. ${ }^{16}$ Divorce was more tolerated under Roman law than under rabbinic law. Yet InstoneBrewer calls Papyrus Se'elim "a curious blend of orthodox terminology and Egyptian-Jewish divorce practice" - there is no doubt that this fragmentary document comes from a Judaic tradition. ${ }^{17}$ The EgyptianJewish practice he refers to is, the divorce proceedings outlined in the Elephantine marriage contracts. Papyrus Se'elim 13 shares with those contracts not just the idea of divorce as a legal reality, but also as a financial contingency in which certain obligations must be fulfilled. All theories seem to agree that lines 8-9, "I do not have with you, Eleazar, anything I wish for," relate to a financial agreement not to seek any further monetary compensation. ${ }^{18}$ There is also the implication that payment had already been received as outlined in the ketubba (marriage contract). Regardless of whether it was the husband or the wife who instigated the divorce mentioned in Papyrus Se'elim 13, it is clear there were provisions made for women within the institution of 
divorce at this time. Whether or not women had the right to initiate divorce on grounds of 'hatred' as they did at Elephantine, Papyrus Se'elim 13 demonstrates that women at least had the right to receive monetary compensation and could not be divorced without consideration. Although Papyrus Se'elim 13 seems in some ways to indicate a similarly practical view on divorce to that found at Elephantine, it is important to consider that marriage and divorce were primarily religious institutions and thus must have, to some extent, been influenced by scripture.

When examining these documents in a scriptural context, it becomes apparent that just as Papyrus Se'elim 13 represents a temporal progression of nearly six hundred years from the earliest of the Elephantine contracts, the writings of the Hebrew Bible also cover a large period of time. J. $H$. Otwell summarizes that biblical dating according to historical criticism and situates the Old Testament documents between the beginning of the twelfth century BCE and the early second century BCE, a period of roughly one thousand years. ${ }^{19}$ The book of Hosea, which I will discuss as one example of divorce in the Hebrew Bible, may date from as early as the eighth century BCE. However, it was probably not collected in its present scriptural form until the fourth century BCE, perhaps a hundred years after the Elephantine contracts. $^{20}$ Still, Hosea provides an interesting case study of divorce in the Old Testament, because it could be contemporaneous with the archives at Elephantine 
and was definitely in use as scripture by the Roman period and the time of Papyrus Se'elim 13. In regards to the codification of marriage and divorce law in the Hebrew Bible, slightly earlier scriptural sources will be used: Exodus and Deuteronomy. In Social Visions of the Hebrew Bible, J. D. Pleins posits that the younger of the two Old Testament law code sources examined here, Deuteronomy, was finalized during the reign of Josiah, circa 640-609 BCE, or at least 140 years before the oldest of the Elephantine marriage documents. ${ }^{21}$ According to this dating system, both of the scriptural law codes discussed in relation to divorce practices were written and in use in the Judaic community by the time the Elephantine contracts were composed, and before Papyrus Se'elim 13 was written. The divorce laws in Exodus and Deuteronomy are therefore equally applicable to a discussion of both the contracts from Elephantine and Papyrus Se'elim 13.

In his discussion of divorced women's rights in the Old Testament, Otwell claims that "no instance of a wife securing a divorce is reported in the Old Testament." 22 Yet if laws relating to divorce are codified in Exodus and Deuteronomy, there must be some scriptural examples of divorce. One such prominent example can be found at Hosea 2:2, when Hosea repudiates his wife, Gomer, with a statement reminiscent of the Elephantine contracts: "for she is not my wife, and I am not her husband." It is clear in context that Hosea has ended their marriage on grounds of infidelity. Gomer's act of infidelity becomes 
symbolic of the larger infidelity of Israel towards God, and Hosea's divorce thus serves as a warning against unfaithfulness. ${ }^{23}$ In this case, the husband divorces the wife, and divorce is clearly not an end to be wished for. Hosea 2:4 states, "Upon her children also I will have no pity," implying that Hosea's divorce is intended as an act of punishment toward Gomer and her offspring. Nevertheless, Hosea does provide us with a concrete example of divorce in the Old Testament and even the grounds for that divorce: infidelity.

Adultery as grounds for divorce is also mentioned in the latest and most complex of the three Elephantine marriage contracts, the document of wifehood relating to Jehoishma's marriage to Ananiah. In addition to repudiation by declaration of hatred, this Elephantine contract also has specific clauses for "repudiation by conduct" by both husband and wife, in which infidelity, or the acquisition of another spouse, resulted in divorce, "the law of hatred." 24 Unlike the Elephantine contracts or even Papyrus Se'elim 13, Hosea does not consider a case in which the wife may wish to divorce her husband or might profit by it in any way. In fact, Hosea seems to go directly against the inference, implicit in Papyrus Se'elim 13, that there was a requirement for both parties in the divorce to meet some sort of pre-arranged financial obligation. Hosea 2:7-8 speaks to the wife's desire to return to the husband who has divorced her and to the husband's role as the provider. ${ }^{25}$ The suggestion is that without her former husband, the ex- 
wife could not prosper. As a result, the book of Hosea does not foresee a situation in which the wife might initiate the divorce.

In Exodus 21:10-11, however, there may be evidence of the wife's right to divorce on her own behalf. This passage seems to outline specific conditions under which the wife had the right to seek divorce from her husband, rather than the more usual situation where the husband divorced his wife, as seen in Hosea. Although the woman in question is undoubtedly a slave, the stipulation "if he takes another wife to himself" seems to suggest that she was a slave wife or at least a concubine. ${ }^{26} \mathrm{D}$. InstoneBrewer considers the woman in Exodus 21:10 to be clearly a slave wife, married to her master, and in this case the verse can be seen to provide a list of basic requirements on the husband's part for fulfillment of a marriage contract. ${ }^{27}$ In this light, Exodus 21:11 seems to offer a divorce clause paralleling the repudiation clauses in the Elephantine contracts. The language in Exodus 21:11 "she shall go out" even echoes similar lines in the Elephantine contracts detailing the wife's action in leaving her husband's household upon initiating divorce. According to Exodus, a declaration of hatred was not grounds enough for divorce in the case of a marriage contract, although there still seemed to be room for divorce if the husband was found to be in direct breach of contract specified in 2:10. Otwell quotes D. R. Mace on the subject, saying "If this were true of a mere concubine, one would expect it to hold good a fortiori in 
the case of a wife." 28 At Elephantine, the document of wifehood detailing the handmaiden Tamet's marriage to Ananiah, a free man, gave Tamet the same right to divorce as the free women in the other Elephantine contracts. $^{29}$ At least in this diasporic community, Mace's theory seems to hold true. If all wives could not initiate divorce as freely as suggested in the Elephantine contracts, Exodus indicates that under circumstances of denial of her basic spousal rights, a woman was entitled to an end to the marriage on her own behalf. She would then be allowed to "go out" from her husband's household and presumably seek a better marriage elsewhere.

Male-initiated divorce is the subject of the later Deuteronomy 24:1-4 which provides a law-code limiting a husband from re-marrying a former wife after she had taken a second husband. There is a potential argument here that, since Deuteronomy is more recent than Exodus and may represent a revision of the older laws codified in Exodus, perhaps divorce by the wife fell out of favour and ceased to be practiced. ${ }^{30}$ On the other hand, the Deuteronomic Codes anticipate the potential for a wife to be divorced not just once, but multiple times. The need to place codified limits on divorce is evidence of their existence. According to Pleins, the strong focus on marriage and marital law - and hence, divorce - in the Deuteronomic Codes results from an update of the older law codes in Exodus to reflect a more urban setting, focused around Jerusalem. ${ }^{31}$ 
Following this train of logic, it seems likely that as the locus of scriptures became more urban and the ancient Judaic empire became more centralized, incidences of divorce may even have increased, thus explaining the apparent requirement for more scriptural regulation of divorce practices. This does not account for the fact that, in Deuteronomy, it is always the wife who was divorced by her husband, and not the reverse. ${ }^{32}$ If the assigned date for the Deuteronomic Codes is correct, the Elephantine contracts give us documentary evidence of a Judaic community less than two centuries later where it seemed that divorce by the female party was at the very least possible. This apparent contradiction between scripture and practice is one of the problems underlying the inconclusive scholarly opinion about Papyrus Se'elim 13. Because extant documentary sources are so lacking, a dilemma persists. Either the practices at Elephantine were an anomalous result of geographical separation from Ancient Palestine and the source of the scriptures, or feminist readings of Papyrus Se'elim 13 are correct and despite lack of support from the later scriptural sources like Hosea and the Deuteronomic Codes, divorce by the wife was practiced centuries later in Palestine as well.

Divorce was strictly regulated, in scriptural sources, but the small amount of documentary evidence indicates that where accepted grounds for divorce existed, it was certainly practiced to some extent. This was true both in earlier diasporic communities like Elephantine and much 
later, in Romano-Judaic Palestine. Furthermore, this evidence suggests despite lack of specific scriptural precedents, there were in some cases grounds upon which women were able to divorce their husbands. These grounds appear to be concretely defined in Exodus. At Elephantine, the only hard definition for a divorce case seems to have been 'hatred,' as laid out in the marriage contracts. During the Roman period, if Papyrus Se'elim 13 even represents divorce initiative from the wife, all information about the divorce case itself has been lost. While this range of primary sources provides a temporally broad range of reference, it is also composed of extremely sparse evidence outside of scriptural texts. What little evidence there is, in the form of the documents from Elephantine and Se'elim, raises additional questions of outside influence on Judaic culture and divorce practices. Both Instone-Brewer and Nutkowicz address the fact that the Elephantine documents were, after all, written in Egypt - a culturally mixed settlement. ${ }^{33}$ Divorce may have been a considerably more common event there than in most contemporaneous Israelite cultures. Although the Papyrus Se'elim 13 originates in Palestine, the area had heavy Greco-Roman cultural influences. It is difficult to determine how accurately these sources reflect practices in the ancient Judaic community as a cultural whole, especially given the lack of documentary evidence in the interim between the writings from Elephantine and Papyrus Se'elim 13. But the sources do indicate that, at 
least on a limited-case basis, in some aspects of the Judaic community Israelite women could initiate divorce.

${ }^{1}$ A. Untu, "Feminine Private Roles in Ancient Near East a Comparative Study with a Stress on the Israelite Woman's Condition," Studia Hebraica 7 (2007): 195.

2 See: T. Ilan, "Notes and Observations on a Newly Published Divorce Bill from the Judean Desert," Harvard Theological Review 89 (I996): 195-202.

${ }^{3}$ A Jewish divorce bill, or get, dated to $72 \mathrm{CE}$ and published in $196 \mathrm{I}$ by Jozef Milik. For further discussion of the Masada get in relation to Papyrus Se'elim I3, see: Ilan, "Notes and Observations."

${ }^{4}$ Unless otherwise noted, all biblical citations are from the Revised Standard Version text (RSV).

${ }^{5}$ Scripture, of course, is itself a documentary source. I make the distinction here between "documentary" and "scriptural" in order to clarify the discussion of the Elephantine documents and Papyrus Se'elim I 3 versus the discussion of the Old Testament.

${ }^{6}$ B. Porten, "Egyptian Aramaic," in The Context of Scripture: Archival Documents from the Biblical World, ed. William W. Hallo and K. Lawson Younger, Jr. (Leiden: E. J. Brill, 2003), I53, I7I, I82.

${ }^{7}$ The translations used throughout this discussion of the Elephantine Marriage contracts are from Porten, "Egyptian Aramaic," I53-I57, I7I-I73, I82186.

${ }^{8}$ Ibid., I55-I56. The contract quoted is the simplest of the three wifehood documents, detailing the marriage of Mibtahiah to Eshor.

${ }^{9}$ H. Nutkowicz, "Concerning the Verb śn' in Judaeo-Aramaic Contracts from Elephantine," Journal of Semitic Studies 52 (2007): 218.

${ }^{10}$ Essentially the male equivalent of the dowry, the mohar was the price paid by the groom to the father of the bride. It was usually substantially lower than the dowry price.

${ }^{11}$ Porten, "Egyptian Aramaic," I56, I73, 184.

12 Nutkowicz, "Concerning the Verb śn'," 218.

13 Porten, "Egyptian Aramaic," I7I-I73.

14 Ilan, “Notes and Observations," 195. Ilan dates Papyrus Se'elim I 3 to 135 CE.

${ }^{15}$ These views belong, in order, to the various translations of A. Yardeni, T. Ilan, A. Schremer, and D. Instone-Brewer. See: Ilan "Notes and Observations."; A. Schremer, "Divorce in Papyrus Se'elim 13 Once Again: A Reply to Tal Ilan," Harvard Theological Review 91 ( 1998): 193-202; and D. Instone-Brewer, "Jewish Women Divorcing Their Husbands in Early Judaism: The Background to Papyrus Se'elim 13," Harvard Theological Review 92 (1999): 349-357.

${ }^{16}$ Ancient Palestine fell under Seleucid rule in the second century BCE, and remained under Seleucid control until 63 BCE, with the Roman conquest. P. Schäfer, The History of the Jews in the Greco-Roman World (London: Routledge, 2003), 27.

${ }^{17}$ Instone-Brewer, “Jewish Women Divorcing Their Husbands," 357. 
${ }^{18}$ This quotation is from lines 8-9 of the translation by Adiel Schremer. A. Schremer, "Divorce in Papyrus Se'elim I3," 202.

19 J. H. Otwell, And Sarah Laughed: The Status of Women in the Old Testament (Philadelphia: Westminster Press, 1977), 12.

${ }^{20}$ N. P. Lemche, The Old Testament Between Theology and History: A Critical Survey (Louisville, Kentucky: Westminster John Knox Press, 2008), 97.

${ }^{21}$ J. D. Pleins, Social Visions of the Hebrew Bible: A Theological Introduction (Louisville, Kentucky: Westminster John Knox Press, 200I), 75; Lemche, The Old Testament Between Theology and History, 77.

${ }^{22}$ Otwell, And Sarah Laughed, 120.

${ }^{23}$ For commentary on Hosea's marriage and Gomer's infidelity as a metaphor for Israel's covenant with and faithlessness towards God, see Otwell, And Sarah Laughed, I I6-I I 9. Also see especially Pleins, Social Visions, 354-363.

${ }^{24}$ Porten, "Egyptian Aramaic," 185.

25 "She shall pursue her lovers, but not overtake them; and she shall seek them, but shall not find them. Then she shall say, 'I will go and return to my first husband, for it was better with me then than now.' And she did not know that it was I who gave her the grain, the wine, and the oil, and who lavished upon her silver and gold which they used for Ba'al." Hosea 2:7-8.

${ }^{26}$ Exodus 21:10; my italics.

${ }^{27} \mathrm{D}$. Instone-Brewer, Divorce and Remarriage in the Bible: the Social and Literary Context (Grand Rapids: Wm. B. Eerdmans, 2002), 9.

${ }^{28}$ Otwell, And Sarah Laughed, 121.

${ }^{29}$ Porten, "Egyptian Aramaic," I7I-I73.

${ }^{30}$ Pleins, Social Visions, 55.

${ }^{31}$ Ibid., 59.

32 Otwell, And Sarah Laughed, I2 I- 122.

33 Instone-Brewer, "Jewish Women Divorcing their Husbands.";

Nutkowicz, "Concerning the Verb śn'." 